\title{
Hubungan Tingkat Keteraturan Berolahraga Terhadap Komplikasi Penyakit pada Pasien DM Tipe 2 di Poliklinik Endokrin RSUP DR. M. Djamil Padang
}

\author{
Reza Ekatama Rajasa ${ }^{1}$, Afriwardi ${ }^{2}$, Setia Budi Zein ${ }^{3}$
}

\begin{abstract}
Abstrak
Ada banyak faktor yang mempengaruhi komplikasi pada pasien DM tipe 2, salah satunya adalah keteraturan berolahraga. Aktivitas fisik yang kurang akan berisiko terjadinya hiperglikemia. Kondisi ini lambat laun akan menyebabkan kerusakan mikrovaskular dan makrovaskular. Olahraga yang teratur dapat membuat normal gula darah. Tujuan penelitian ini adalah meneliti lebih lanjut tentang hubungan keteraturan berolahraga terhadap komplikasi DM tipe 2. Penelitian ini dilakukan pada masyarakat yang berkunjung ke poliklinik RSUP Dr. M. Djamil Padang. Ini merupakan studi retrospektif dengan jumlah subjek 73 orang. Pengumpulan data responden dilakukan dengan wawancara dan rekam medis. Analisis statistik yang digunakan adalah uji chi-square. Hasil penelitian ini menunjukkan bahwa $65,8 \%$ responden menderita 3 atau lebih komplikasi (banyak), sedangkan 34,2\% menderita kurang dari 3 komplikasi (sedikit). Kesimpulan studi ini adalah terdapat hubungan antara keteraturan berolahraga dengan komplikasi DM tipe 2.
\end{abstract}

Kata kunci: keteraturan berolahraga, komplikasi DM tipe 2

\begin{abstract}
There are many factors correlate to complications in type 2 diabetes mellitus (DM) patients, one of them is exercise regularity. Lack of physical activity can lead to the hiperglycemia condition. It could be the cause of micovascular and macrovascular injuries. Exercise regularity can lead blood glucose toward normal. The objective of this study was to investigate the correlation of exercise regularity to the type 2 DM complications. The research was conducted to the people who visit polyclynic of M. Djamil Hospital. It is a retrospective study with 73 subjek. Data collection was performed through interviews and using medical records. The statistical analysis was performed chisquare test.The result of this research found that $65.8 \%$ of respondent had many complication (three or more), whereas $34.2 \%$ of had less than three complications. Analysis by chi square test, concluded that there was a significant relation between exercise regularity and complications of type 2 DM.
\end{abstract}

Keywords: exercise regularity, complication of type II DM

\begin{abstract}
Affiliasi penulis: 1. Pendidikan Dokter FK UNAND (Fakultas Kedokteran Universitas Andalas Padang). 2. Bagian Fisiologi FK UNAND, 3. Bagian Anatomi FK UNAND

Korespondensi: Reza Ekatama Rajasa,

Email:ejaekatama@gmail.com, Telp: 081513230955
\end{abstract}

\section{PENDAHULUAN}

Diabetes Melitus merupakan salah satu penyakit metabolik yang menyebabkan hiperglikemia. Diabetes Melitus(DM) terjadi karena adanya interaksi yang kompleks dari genetik yaitu pada gen insulin dan faktor-faktor lingkungan. Hal tersebut menyebabkan terjadinya penurunan produksi insulin, penurunan penggunaan glukosa dan peningkatan produksi glukosa. Akibat hal tersebut, terjadinya disregulasi sistem endokrin yang menyebabkan muncul nya komplikasi-komplikasi yang bersifat kronik maupun bersifat akut. ${ }^{1,2}$ Penyakit DM terjadi seiring dengan kemajuan zaman dan kesejahteraan masyarakat, contohnya di Indonesia yang lebih dari 60 tahun merdeka, pola penyakit di Indonesia mengalami 
pergeseran. Penyakit menahun yang disebabkan oleh penyakit degeneratif meningkat secara berarti. Perubahan pola penyakit tersebut diduga ada hubungannya dengan cara hidup yang berubah, antara lain pola makan yang berubah, komposisi makanan yang berubah, aktivitas sehari-hari yang cenderung duduk di belakang meja dan kurangnya waktu untuk melakukan olahraga.,

Pada tahun 2013, penderita DM di seluruh dunia berjumlah 382 juta jiwa. Diantaranya terdapat 138 juta penderita pada Asia Tenggara beserta Australia, 72 juta jiwa pada Asia Selatan beserta Asia Timur, 35 juta jiwa pada Asia Tengah beserta Afrika Utara, 20 juta jiwa pada Afrika, 56 juta jiwa pada Eropa, 24 juta jiwa pada Amerika tengah beserta Amerika Selatan dan yang terakhir terdapat 37 juta jiwa pada Amerika Utara beserta Kepulauan Karibia. Negara China menduduki peringkat teratas pada tabel penderita DM di dunia dengan jumlah 98,4 juta jiwa penderita DM. Sedangkan peringkat kedua ditempati oleh India dengan jumlah penderita sebanyak 65,1 juta jiwa penderita. Peringkat ketiga ditempati oleh United States of America (USA) dengan jumlah penderita sebanyak 24,4 juta jiwa.Pada tahun 2013 Indonesia berdiri pada posisi ketujuh dengan jumlah penderita sebanyak 8,5 juta jiwa. Jumlah penderita DM ini diperkirakan akan meningkat pada tahun 2035, yaitu sebanyak 592 juta jiwa penderita, dapat diartikan bahwa akan terjadi peningkatan penderita sebanyak $55 \%$ dari tahun 2013 sampai 2035 . $^{3}$

\section{METODE}

Penelitian ini dilakukan pada poliklinik endokrin RSUP Dr. M Djamil. Subjek penelitian ini diambil sebanyak 73 pasien DM Tipe II yang memiliki kriteria inklusi dan tidak memiliki kriteria eksklusi. Teknik pengambilan sampel ini menggunakan teknik consecutive sampling. Instrumen yang digunakan pada penelitian ini adalah kuesioner dan data rekam medik pasien DM tipe II. Data yang diperoleh diolah dan diuji statistik dan uji korelasi dengan menggunakan chi-square.
HASIL

Tabel 1. Distribusi responden berdasarkan usia dan jenis kelamin

\begin{tabular}{lll}
\hline Karakteristik & $\mathbf{n}$ & $\%$ \\
\hline Usia & 22 & 30,1 \\
$41-55$ tahun & 45 & 61,6 \\
$56-70$ tahun & 6 & 8,3 \\
$71-85$ tahun & 73 & 100 \\
\hline Total & 32 & 43,8 \\
\hline Jenis Kelamin & 41 & 56,2 \\
Laki-laki & 73 & 100 \\
\hline Perempuan & & \\
\hline Total &
\end{tabular}

Pada penelitian ini responden kelompok usia 56-70 tahun lebih banyak dibandingkan kelompok usia 41-55 dan usia 71-85 tahun yaitu sebesar 61,6\%. Berdasarkan kelompok jenis kelamin, perempuan lebih banyak dibandingkan laki-laki yaitu sebesar $56,2 \%$.

Tabel 2. Distribusi responden berdasarkan keteraturan berolahraga

\begin{tabular}{lll}
\hline Kelompok & $\mathbf{n}$ & $\%$ \\
\hline Tidak teratur & 42 & 57,5 \\
Teratur & 31 & 42,5 \\
\hline Total & 73 & 100 \\
\hline
\end{tabular}

Berdasarkan Tabel 2 dapat dilihat bahwa berdasarkan sampel yang ada, ditemukan sebanyak $42(57,5 \%)$ responden tidak melakukan olahraga secara teratur dan sebanyak $31(42,5 \%)$ responden melakukan olahraga secara teratur. Pengelompokan tersebut didapat berdasarkan kriteria olahraga teratur, yaitu dengan frekuensi lebih atau sama dengan tiga kali seminggu dengan jangka waktu 30-45 menit setiap melakukan olahraga.

Tabel 3. Distribusi responden berdasarkan adanya nefropati diabetikum

\begin{tabular}{lll}
\hline Kelompok & $\mathbf{n}$ & $\%$ \\
\hline Tidak ada & 24 & 32,9 \\
Ada & 49 & 67,1 \\
\hline Total & 73 & 100 \\
\hline
\end{tabular}


Tabel 3 memperlihatkan responden yang terkena nefropati diabetikum ada sebanyak 49 responden atau $67,1 \%$ dari total responden, sedangkan yang tidak terkena ada sebanyak 24 responden atau 32,9\% dari total responden. Diagnosis nefropati ditegakkan berdasarakan hasil rekam medis yang menunjukkan adanya proteinuria (+) atau lebih pada pemeriksaan sedimen urin.

Tabel 4. Distribusi responden berdasarkan adanya retinopati diabetikum

\begin{tabular}{lcc}
\hline Kelompok & $\mathbf{n}$ & $\%$ \\
\hline Tidak ada & 39 & 53,4 \\
Ada & 34 & 46,6 \\
\hline Total & 73 & 100 \\
\hline
\end{tabular}

Berdasarkan Tabel 4 didapatkan penderita retinopati diabetikum sebanyak 34 responden atau sebanyak $46,6 \%$ dari total responden, sedangkan yang tidak menderita retinopati diabetikum sebanyak 39 responden. Diagnosis ini ditegakkan dengan pemeriksaan funduskopi pada mata dengan hasil ditemukannya perdarahan, pembuluh darah baru dan mikroaneurisma pada mata, yaitu bintik merah berdiameter 15-60 $\mu \mathrm{m}$, pemeriksaan ini dilihat dari hasil rekam medis pasien.

Tabel 5. Distribusi responden berdasarkan adanya hipertensi

\begin{tabular}{lll}
\hline Kelompok & $\mathbf{N}$ & $\%$ \\
\hline Tidak ada & 22 & 30,1 \\
Ada & 51 & 69,9 \\
\hline Total & 73 & 100 \\
\hline
\end{tabular}

Penderita hipertensi pada Tabel 5 sebanyak 51 responden atau $69,9 \%$ dari total responden, sedangkan yang tidak menderita hipertensi sebanyak 22 responden. Diagnosis hipertensi ditegakkan berdasarkan hasil rekam medis pada responden yang mengikuti aturan JNC VII yaitu tekanan darah sistolik 140-159 $\mathrm{mmHg}$ atau tekanan darah diastolik 80-89 $\mathrm{mmHg}$ atau melebihi.
Tabel 6. Distribusi responden berdasarkan adanya neuropati diabetikum

\begin{tabular}{lll}
\hline Kelompok & $\mathbf{n}$ & $\%$ \\
\hline Tidak ada & 24 & 32,9 \\
Ada & 49 & 67,1 \\
\hline Total & 73 & 100 \\
\hline
\end{tabular}

Pada Tabel 6 terdapat 49 responden terkena neuropati diabetikum atau $67,9 \%$ dari seluruh responden, sedangkan sebanyak 24 responden tidak terkena neuropati diabetikum. Diagnosis ini ditegakkan berdasarkan hasil rekam medis responden dengan ada rasa kebas, mati rasa, rasa terbakar, tebal, rasa seperti ditusuk dan dirobek.

Tabel 7. Distribusi responden berdasarkan adanya penyakit jantung koroner

\begin{tabular}{lll}
\hline Kelompok & $\mathbf{n}$ & $\%$ \\
\hline Tidak ada & 56 & 76,7 \\
Ada & 17 & 23,3 \\
\hline Total & 73 & 100 \\
\hline
\end{tabular}

Tabel 7 menunjukkan bahwa pada penelitian ini terdapat 17 responden yang terkena penyakit jantung koroner atau hanya sebanyak $23,3 \%$ dari seluruh responden, sedangkan yang tidak terkena PJK yaitu sebanyak 56 responden atau sebanyak $76,7 \%$ dari semua responden. Diagnosis ini ditegakkan berdasarkan pemeriksaan penunjang terdapat peningkatan biomarker pada jantung (troponin dan Creatin Kinase Myocardial Band) dan pada EKG ditemukan elevasi ST atau depresi ST.

Tabel 8. Jumlah komplikasi responden

\begin{tabular}{lll}
\hline Kelompok & $\mathbf{n}$ & $\%$ \\
\hline$\geq 3$ & 48 & 65,8 \\
$<3$ & 25 & 34,2 \\
\hline Total & 73 & 100 \\
\hline
\end{tabular}

Tabel 8 menunjukan bahwa terdapat 48 responden yang dikategorikan $\geq 3$ atau sebanyak $65,8 \%$ dari seluruh responden, dan terdapat 25 responden yang dikategorikan $<3$ komplikasinya. 
Tabel 9. Hubungan keteraturan berolahraga dengan komplikasi DM tipe 2

\begin{tabular}{lllllllll}
\hline $\begin{array}{l}\text { Keteraturan } \\
\text { olahraga }\end{array}$ & $\begin{array}{c}c \\
\text { Komplikasi DM tipe 2 }\end{array}$ & \multicolumn{2}{l}{ Total } & & & \\
& $\mathbf{n}$ & $\%$ & $\mathbf{n}$ & $\%$ & $\mathbf{n}$ & $\%$ & \\
\hline Teratur & 17 & 54,8 & 14 & 45,2 & 31 & 100 & \\
$\begin{array}{l}\text { Tidak } \\
\text { Teratur }\end{array}$ & 8 & 19 & 34 & 81 & 42 & 100 & 0,000 \\
\hline
\end{tabular}

Berdasarkan Tabel 9 dapat dilihat propors orang yang berolahraga teratur ada sebanyak 31 responden dan sebanyak 42 orang yang berolahraga tidak teratur. Pada hasil pengolahan data menggunakan chi-square di atas, dapat dilihat bahwa didapatkan nilai $\mathrm{p}=0,000$ (dimana nilai $\mathrm{p}$ yang dianggap bermakna adalah <0,05), yang artinya terdapat perbedaan yang bermakna antara banyak komplikasi pada orang yang teratur berolahraga dengan orang yang tidak teratur berolahraga. Artinya, orang yang teratur berolahraga memiliki komplikasi yang cenderung lebih sedikit dibandingkan orang yang tidak teratur berolahraga.

\section{PEMBAHASAN}

Penelitian ini merupakan studi analitik dengan menggunakan desain penelitian retrospective study. Data penelitian diperoleh dari data primer penderita DM tipe II dan data sekunder dari hasil rekam medis pasien DM tipe 2 di Poliklinik Khusus Endokrin RSUP Dr. M. Djamil Padang.

Pada penelitian ini digambarkan keterkaitan antara keteraturan berolahraga pasien DM tipe 2 terhadap komplikasi yang telah ada pada pasien DM tersebut. Penelitian ini dilakukan di Poliklinik Khusus Endokrin RSUP M. Djamil Padang agar sampel yang didapatkan homogen. Rata-rata pasien DM yang ditemukan telah berumur lebih dari 60 tahun dan tidak jarang pasien memiliki penyakit selain DM yang mempengaruhi komplikasi DM. Penelitian ini hanya melihat lima komplikasi, yaitu: PJK, Nefropati Diabetikum, Neuropati Diabetikum, Retinopati Diabetikum dan Hipertensi karena lima komplikasi ini merupakan komplikasi kronis yang dipengaruhi oleh keteraturan olahraga dan juga kelima komplikasi ini dapat dilihat pada hasil rekam medis pasien.
Penelitian ini dilakukan terhadap 73 orang responden yang terdiri dari 32 laki-laki dan 41 perempuan. Proporsi subjek perempuan lebih besar $(56,2 \%)$. Jumlah responden kelompok usia 56-70 tahun lebih banyak $(61,6 \%)$ dibanding kelompok usia yang lain. Semua responden berumur diatas 40 tahun dimana penderita DM tipe 2 rata-rata beumur diatas 40 tahun. $^{1}$

Pada penelitian ini didapatkan gambaran mengenai banyaknya komplikasi pada setiap pasien DM tipe 2 yang peneliti teliti Komplikasi yang dilihat pada penelitian ini adalah PJK, nefropati diabetikum, neuropati diabetikum, hipertensi dan retinopati diabetikum. Pada penelitian ini didapatkan penderita PJK sebanyak 23,3\%, nefropati diabetikum sebanyak $67,1 \%$, retinopati diabetikum sebanyak $46,6 \%$, hipertensi sebanyak $69,9 \%$ dan neuropati diabetikum sebanyak $67,1 \%$.

Hiperglikemia pada pasien DM akan menyebabkan beberapa mekanisme yang dijelaskan dalam empat teori. Teori yang pertama yaitu terbentuknya advanced glycolysation end product (AGEs) akibat meningkatnya glukosa intrasellular yang akan menyebabkan ateroslerosis, disfungsi glomerular, menurunkan sintesis nitric oxide, disfungsi endotel, perubahan komposisi dan struktur matriks ekstraselular. Teori yang kedua yaitu: metabolisme glukosa meningkat dan akan mengubah glukosa tersebut menjadi sorbitol oleh enzim aldose reductase. Hal tersebut akan menyebabkan kerusakan pada pembuluh darah. Teori ketiga akibat terbentuknya protein kinase $\mathrm{C}$ yang juga akan merusak endotel pembuluh darah. Teori yang ke empat yaitu berkaitan dengan hexosamine pathway yang akan mengubah supressi gen transforming growth factor (TGE- $\beta$ ) dan plasminogen activator inhibitor-1(PAl-1) yang akan mengakibatkan perubahan growth factor. ${ }^{1,5}$

Berdasarkan kepustakaan, keteraturan berolahraga memiliki hubungan dengan munculnya komplikasi. Beberapa penelitian sebelumnya telah membuktikan bahwa kurangnya aktivitas fisik dapat meningkatkan risiko terjadinya berbagai penyakit terutama penyakit sindroma metabolik salah satunya DM. Olahraga teratur seperti adalah jalan, lari, berenang dan naik sepeda dapat menjaga kebugaran, menurunkan berat badan dan yang paling penting 
adalah dapat memperbaiki sensitifitas insulin sehingga dapat memperbaiki kendali gula darah. Sedangkan aktivitas fisik yang rendah dapat menurunkan produksi NO yang secara parallel menurunkan produksi endothelial drive relaxing factor (EDRF) sehingga menyebabkan kerusakan pembuluh darah. Pada penelitian sebelumnya didapatkan 30\%-50\% subyek dengan aktivitas fisik yang rendah akan menjadi hipertensi. ${ }^{4,5}$

Pada DM tipe 2, olahraga banyak memberikan manfaat antara lain: menurunkan berat badan sehingga mengurangi jumlah lemak dalam tubuh, mencegah komplikasi pada penyakit ini dengan menurunkan tekanan darah, mengurangi lemak, meningkatkan kebugaran jasmani, meningkatkan kesehatan jantung dan juga member dampak psikologis yang baik. Manfaat yang paling penting adalah meningkatkan sensitifitas reseptor insulin yang merupakan masalah utama pada DM tipe Meningkatnya penggunaan glukosa juga merupakan peran dari GLUT4 yang merupakan protein struktural penghantar glukosa. Dengan mengkontraksikan otot rangka, GLUT4 akan semakin banyak dihasilkan dan akan memperbaiki atau meningkatkan absorbsi glukosa pada sel, terutama pada sel-sel otot rangka. ${ }^{6}$

Hasil penelitian ini menunjukkan hubungan yang sesuai dengan beberapa hasil penelitian di atas. Hubungan keteraturan berolahraga dengan komplikasi DM tipe 2 didapatkan ada hubungan yang bermaknadengan nilai $p=0,000(p<0,05$ menunjukkan hubungan bermakna).

\section{KESIMPULAN}

Terdapat hubungan yang bermakna antara keteraturan berolahraga dengan komplikasi DM tipe II.

Terdapat hubungan yang bermakna antara keteraturan berolahraga dengan nefropati diabetikum.

Terdapat hubungan yang bermakna antara keteraturan berolahraga dengan neuropati diabetikum.

Terdapat hubungan yang bermakna antara keteraturan berolahraga dengan hipertensi.

Terdapat hubungan yang bermakna antara keteraturan berolahraga dengan retinopati diabetikum.
Terdapat hubungan yang tidak bermakna antara keteraturan berolahraga dengan penyakit jantung koroner.

\section{DAFTAR PUSTAKA}

1. Fauci AS. Harisson. principle of internal medicine. Edisi ke-17. United States: The McGrawahill Companies.2008. hlm.924-9.

2. Suyono S. Diabetes melitus di Indonesia. Dalam. Dalam: Sudoyo AW, Setiyohadi B, Alwi I, Simadibrata $M$, Setiati $S$, editor (penyunting). Buku Ajar IImu Penyakit Dalam Jilid I. Jakarta: Pusat Penerbitan Departemen IImu Penyakit Dalam FKUI Interna Publishing; 2009.hlm.1874-8.

3. International Diabetes Federation. Diabetes Atlas. 2013. (diunduh 20 Februari 2014). Tersedia dari: URL: HYPERLINK http://www.idf.org/diabetesatlas

4. Darmasari E. Hubungan konsumsi antioksidan dengan tekanan darah pada masyarakat di Sumatera Barat (tesis). Padang: Universitas Andalas; 2010.

5. Waspadji S. Komplikasi kronis diabetes mellitus. Dalam: Sudoyo AW, Setiyohadi B, Alwi I, Simadibrata $M$, Setiati $S$, editor (penyunting). Buku Ajar IImu Penyakit Dalam Jilid II. Jakarta: Pusat Penerbitan Departemen IImu Penyakit Dalam FKUI Interna Publishing,2009.hlm.1906-10.

6. Hordern, Mathew D, David W. Dunstan.Exercise prescription for patient with type 2 diabetes and pre diabetes: A position statement from Exercise and Sport Science Australia.Journal Science and Medicine in Sport.2011:15; 25-31.

7. Hendromartono. Nefropati diabetik. Dalam: Sudoyo AW, Setiyohadi B, Alwi I, Simadibrata M, Setiati S, editor (penyunting). Buku Ajar IImu Penyakit Dalam Jilid II. Jakarta: Pusat Penerbitan Departemen IImu Penyakit Dalam FKUI Interna Publishing; 2009. hlm.1920-2.

8. Subekti I. Neuropati Diabetik. Dalam: Sudoyo AW, Setiyohadi B, Alwi I, Simadibrata M, Setiati $\mathrm{S}$, editor (penyunting). Buku Ajar IImu Penyakit Dalam Jilid II. Jakarta: Pusat Penerbitan Departemen IImu Penyakit Dalam FKUI Interna Publishing; 2009. hlm.1924-6. 
9. Blair SN, Morris JN. Healthy hearts-and the universal benefits of being physically active: physical activity and health. Ann Epidemiol. 2009; 19:253-6.

10. Arisman. Gizi dalam daur kehidupan. Dalam: Buku Ajar IImu Gizi. Jakarta: EGC; 2004.hlm.51-6.
11. Afriwardi. Ilmu kedokteran olahraga. Jakarta: EGC; 2009.

12. Perkeni. Konsensus pengendalian dan pencegahan DM Tipe 2. Jakarta: Perkeni; 2011. 